\title{
The Origin of Hydrogen Generated from Formaldehyde in Basic Solutions
}

\author{
S. Kapoor, F. Barnabas, C.D. Jonah, M. C. Sauer, Jr. and D. Meisel
}

Chemistry Division

Argonne National Laboratory

Argonne, Ill 60439

RECEIVED

FFA 281996

OSTI

\begin{abstract}
The isotopic composition of dihydrogen generated from formaldehyde in highly basic solutions has been investigated. It is shown that two pathways contribute to the generation of dihydrogen. In the first pathway, one hydrogen atom originates from water and the other from formaldehyde. In the second pathway both hydrogen atoms originate from the methylene moiety of the formaldehyde. For production of dihydrogen from glyoxylate only the first pathway is observed.
\end{abstract}


The generation of $\mathrm{H}_{2}$ in highly alkaline nuclear waste solutions has become of concern in recent years. ${ }^{1}$ There are two possible sources for the generation of dihydrogen in these waste solutions - radiolytic and chemical and these two pathways are interrelated. Formaldehyde and glyoxylate $\left(\mathrm{HCOCO}_{2}-\right)$ are known radiolytic degradation products of organic compounds that are present in these waste solutions. These two aldehydes were recently implicated as sources for $\mathrm{H}_{2}$ evolution from the highly basic solutions. ${ }^{2}$ The $\mathrm{H}_{2}$ evolution reaction is clearly in competition with the well documented Cannizzaro reaction ${ }^{3}$ in which the disproportionation of formaldehyde to the corresponding alcohol and acid occurs in the basic solutions. The mechanism for the Cannizzaro reaction is believed to involve hydride transfer from the singly and doubly ionized forms of the aldehyde-hydrate (methylene glycol) to another aldehyde molecule. ${ }^{4}$

The hydrogen evolution reaction from formaldehyde has received little attention over the years even though it was described over a century ago. ${ }^{5}$ Fry et al. proposed, that the $\mathrm{H}_{2}$ produced in this reaction proceeds to reduce the aldehyde to methanol in the Cannizzaro reaction ${ }^{6}$, a proposition that later gave way to the hydride mechanism. The recent observations of Ashby et al have shown that high conversion ratios of formaldehyde, and other aldehydes that contain no hydrogen atoms $\alpha$ - to the carbonyl, to $\mathrm{H}_{2}$ can be achieved, at very high [OH- ${ }^{2}{ }^{2}$ The mechanism proposed in the latter study requires one hydrogen atom to originate from water and the other from organic moiety. In the present report we confirm that this is the exclusive route for glyoxylate, which has only a single "active" hydrogen. However, for formaldehyde, with its two methylene hydrogen atoms, both atoms in $\mathrm{H}_{2}$ could originate in the organic moiety. Earlier attempts ${ }^{2}$ to use isotopic labeling techniques to study this reaction were defeated by the exchange of hydrogen among hydroxide ions and dihydrogen molecules. ${ }^{7}$

For the experiments described below, $10 \mathrm{ml}$ of $2.3 \mathrm{M} \mathrm{NaOH}$ aqueous solutions in specially designed vessels of approximately $50 \mathrm{ml}$ were evacuated using several freeze-thaw cycles. Formaldehyde (or glyoxylate) was then injected into the solution at ambient temperature to initiate the reaction. The reaction was allowed to proceed for 30 minutes, the gas phase was equilibrated with the aqueous phase by vigorous shaking and the reaction was quenched at $77 \mathrm{~K}$. The gas 
from the head space was then transferred to a mass spectrometer for analysis. Results are summarized in Table 1. The short period of time from initiation to quenching of the reaction ensures very little isotopic exchange between dihydrogen and hydroxide. ${ }^{7}$ The last line in Table 1 shows that, indeed, little exchange occurs in 30 minutes in the system used when $D_{2}$ is injected into basic $\mathrm{H}_{2} \mathrm{O}$ solution. Our kinetic results presented elsewhere ${ }^{8}$ indicate that only a very small fraction of the formaldehyde $(<1 \%)$ is converted to dihydrogen under the experimental conditions used here.

The results for dihydrogen generation from deuterated water containing $\mathrm{NaOD}$ and proteated glyoxylate (Exp. 6 Table 1) agree with a mechanism requiring one water (or water exchangeable) hydrogen and one hydrogen from the aldehyde. The $\sim 7 \% \mathrm{H}_{2}$ in this experiment probably reflects a reaction with the $\sim 1 \%$ proteated water impurity. The preeminent result from the experiments on formaldehyde is the high percentage of mono isotopic dihydrogen, $\mathrm{D}_{2}$ in Exp. 1 to 3 and $\mathrm{H}_{2}$ in Exp. 4,5 of Table 1, that was obtained from the corresponding aldehyde. In particular, the high yield of $\mathrm{D}_{2}$ from the parent $\mathrm{CD}_{2} \mathrm{O}$ is outstanding. Nonetheless, a pathway involving an hydrogen atom from water is also required, to explain the significant percentage of $\mathrm{HD}$. Quantitative analysis of the results in Table 1 would need to consider the isotopic dependence of the two acid-base equilibria of methylene glycol, and the kinetic isotope effect on the dihydrogen generating reactions; the margin of error in the results of Table 1 is too large to attempt such an analysis.

The mono isotopic dihydrogen may originate either from a single or two different formaldehyde molecules. The former is probably the case. A reaction between two formaldehyde molecules is inconsistent with the dependence of the yield on formaldehyde concentrations that has been previously reported and was confirmed in this study. In such a bimolecular reaction the conversion ratio of formaldehyde to $\mathrm{H}_{2}$ would be independent of $\left[\mathrm{CH}_{2} \mathrm{O}\right]$ because the rates of both reactions, the $\mathrm{H}_{2}$ evolution and the Cannizzaro reaction, would have the same concentration dependence. A reaction between two aldehyde molecules to generate $\mathrm{H}_{2}$ is possible for glyoxylate, as well as formaldehyde, but no significant amount of mono isotopic product was obtained in the 
former case. Finally, such a bimolecular reaction is difficult to reconcile with our kinetic results 8 on the reaction order and with the observation of 1:1 ratio of dihydrogen to formate. ${ }^{2}$

To conclude, in the net reaction represented by equations 1 and 2, two pathways for $\mathrm{H}_{2}$

$$
{ }_{\mathrm{H}}^{\mathrm{H}} \mathrm{C}_{\mathrm{OH}}^{\mathrm{OH}^{-}}+\mathrm{OH}-\rightarrow \mathrm{H}_{2}+\mathrm{HCO}_{2}^{-}+\mathrm{OH}^{-}
$$

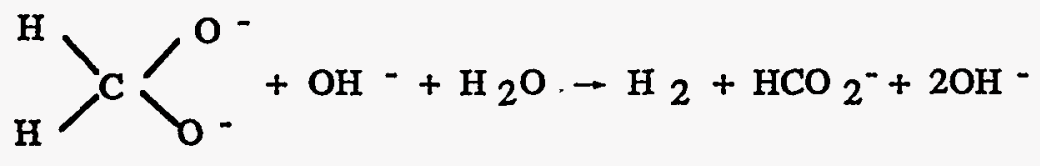

generation must occur. In one, both hydrogen atoms originate from the organic moiety while in the other both water and the aldehyde contribute, one atom each, to the dihydrogen product. The detailed mechanism for these processes is still unclear but we show elsewhere 8 that hydroxide ion is a necessary reactant, perhaps a reductant, in addition to controlling the acid-base forms of the methylene glycol.

\section{Acknowledgments:}

Support of this work by Westinghouse Hanford Company is gratefully acknowledged. 


\section{References}

(1) Levy, B.G., Physics Today, 1992, 45, 17.

(2) Ashby, E. C.; Doctorovich, F.; Liotta, C. L.; Neumann, H. M.; Barefield, E. K.; Konda, A.; Zhang, K.; Hurley, J.; Siemer, D. D., J. Am. Chem. Soc., 1993, 115, 1171.

(3) a. Swain, C. G.; Powell, A. L.; Sheppard, W. A.; Morgan, C. R., J. Am. Chem. Soc., 1979, 101, 3576, and references therein. b. Swain, C. G.; Powell, A. L.; Lynch, T. J.; Alpha, S. R.; Dunlap, R. P., ibid., 3584.

(4) Rodd's Chemistry of Carbon Compounds; 2 ed.; Coffey, S., Ed.; 1965; Vंol. 1c, pp. 11.

(5) Loew, O. Ber., 1887, 20, 144.

(6) Fry, H. S.; Uber, J. J.; Price, J. W., Rec. Trav. Chim., 1931, 50, 1060-5.

(7) a. Wilmarth, W. K.; Dayton, J. C.; Flournoy, J. M., J. Am. Chem. Soc., 1953, 75, 4549. b. Flournoy, J. M.; Wilmarth, W. K., J. Am. Chem. Soc., 1961, 83, 2257.

(8) Kapoor, S., Barnabas, F., Sauer, M. C., Jonah, C. D., Meisel, D., Submitted for publication 
Table 1. Isotopic composition of dihydrogen generated from formaldehyde or glyoxylate in basic solutions of various isotopic compositions ${ }^{\mathrm{a}}$.

\begin{tabular}{|c|c|c|c|c|c|}
\hline Exp. \# & Sample Composition ${ }^{b}$ & $\begin{array}{r}\% \mathrm{I} \\
\mathrm{H}_{2} \\
\end{array}$ & HD & $\begin{array}{l}\mathrm{D}_{2} \\
\mathrm{D}_{2} \\
\end{array}$ & Comments \\
\hline 1 & $\begin{array}{c}0.13 \mathrm{M} \mathrm{CD}_{2} \mathrm{O} \text { in } 2.3 \mathrm{M} \\
\mathrm{NaOH} / \mathrm{H}_{2} \mathrm{O}\end{array}$ & $12 \pm 4.6$ & $19 \pm 7.0$ & $69 \pm 10.0$ & 4 measurements \\
\hline 2 & $\begin{array}{c}0.065 \mathrm{M} \mathrm{CD}_{2} \mathrm{O} \text { in } 2.3 \mathrm{M} \\
\mathrm{NaOH} / \mathrm{H}_{2} \mathrm{O}\end{array}$ & 6.8 & 26 & 67 & $\begin{array}{l}1 \text { measurement } \\
.\end{array}$ \\
\hline 3 & $\begin{array}{c}0.0325 \mathrm{M} \mathrm{CD}_{2} \mathrm{O} \text { in } 2.3 \mathrm{M} \\
\mathrm{NaOH} / \mathrm{H}_{2} \mathrm{O}\end{array}$ & $4.9 \pm 0.4$ & $10.7 \pm 0.5$ & $84.4 \pm 0.2$ & 2 measurements \\
\hline 4 & $\begin{array}{c}0.13 \mathrm{M} \mathrm{CH}_{2} \mathrm{O} \text { in } 2.3 \mathrm{M} \\
\mathrm{NaOD} / \mathrm{D}_{2} \mathrm{O} \\
\end{array}$ & $65.5 \pm 2.1$ & $33.0 \pm 1.4$ & $1.5 \pm 0.7$ & 2 measurements \\
\hline 5 & $\begin{array}{c}0.0325 \mathrm{M} \mathrm{CH}_{2} \mathrm{O} \text { in } 2.3 \mathrm{M} \\
\mathrm{NaOD} / \mathrm{D}_{2} \mathrm{O}\end{array}$ & $40.5 \pm 2.7$ & $59.0 \pm 2.4$ & $0.5 \pm 0.2$ & 2 measurements \\
\hline 6 & $\begin{array}{c}0.13 \mathrm{M} \text { Glyoxylate in } 2.3 \mathrm{M} \\
\mathrm{NaOD} / \mathrm{D}_{2} \mathrm{O}\end{array}$ & $6.5 \pm 3.7$ & $91.8 \pm 3.1$ & $1.8 \pm 0.6$ & 2 measurements \\
\hline 7 & $\begin{array}{c}2.3 \mathrm{M} \mathrm{NaOH} / \mathrm{H}_{2} \mathrm{O} \text { saturated } \\
\text { with } \mathrm{D}_{2}\end{array}$ & 0.25 & 0.84 & 98.9 & $\begin{array}{l}\text { test for } \mathrm{D}_{2} / \mathrm{OH}^{-} \\
\text {exchange }\end{array}$ \\
\hline
\end{tabular}

a Gases extracted 30 min. after injection of $\mathrm{CH}_{2} \mathrm{O}, \mathrm{CD}_{2} \mathrm{O}$ or glyoxylate into the basic solution at room temperature $\left(23.1 \pm 0.2^{\circ} \mathrm{C}\right)$.

b $99 \% \mathrm{D}_{2} \mathrm{O}$ and $99.9 \% \mathrm{NaOD}$ when deuterated medium was used. Formaldehyde-d 2 was $98 \%$.

\section{DISCLAIMER}

This report was prepared as an account of work sponsored by an agency of the United States Government. Neither the United States Government nor any agency thereof, nor any of their employees, makes any warranty, express or implied, or assumes any legal liability or responsibility for the accuracy, completeness, or usefulness of any information, apparatus, product, or process disclosed, or represents that its use would not infringe privately owned rights. Referprocess disclosed, or represents that its use wuct, process, or service by trade name, trademark, ence herein to any specific commercial product, process, or service by trade name, trademark, manufacturer, or otherwise does not necessarily constitute or imply its endorsement, recommendation, or favoring by the United States Government or any agency fhlect those of the and opinions of authors expressed herein do not necessarily state or reflect those of the United States Government or any agency thereof. 